\title{
Quality in Thoracic Surgery
}

Editor

FELIX G. FERNANDEZ

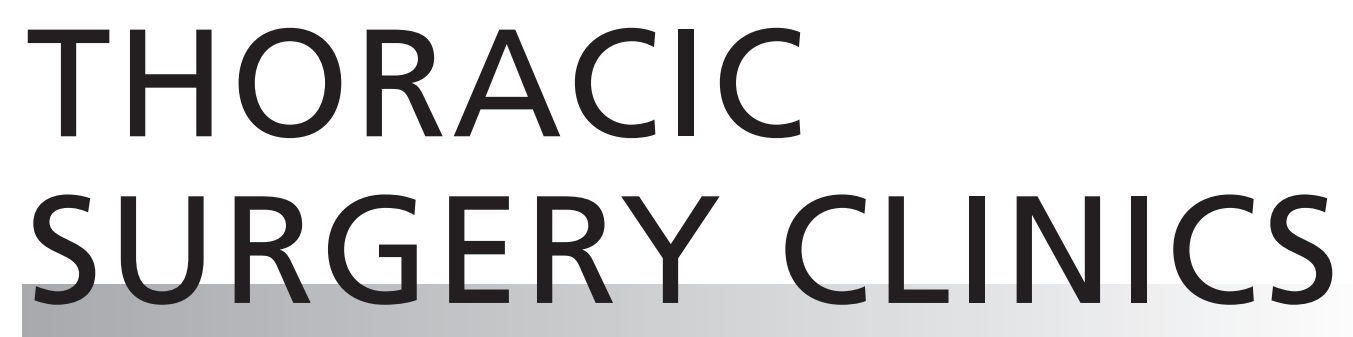

www.thoracic.theclinics.com

Consulting Editor

M. BLAIR MARSHALL

August 2017 • Volume 27 - Number 3 